\title{
THE STARS AND STRIPES WHEREVER: \\ THE IMPACT OF UNILATERAL U.S. ECONOMIC SANCTIONS ON THE INTERNATIONAL PETROLEUM INDUSTRY
}

\section{LYNN R. COLEMAN and THOMAS R. GRAHAM*}

The authors discuss the impact of American domestic policies and electoral politics on the formulation of the international economic laws of the United States. They note a trend towards the attempted extraterritorial application of American international economic legislation and highlight the significance of the Helms-Burton Act and the Iran (Libya) Oil Sanctions Act in this context. It is suggested that these Acts represent an aggressive attempt by the United States to force its traditional allies and trading partners to conform to American international economic policies, and that if not successfully challenged in international fora they may be followed by other similar pieces of legislation. Finally, special attention is paid to the impact and potential impact on the oil industry of these Acts and other American international economic measures.

\section{TABLE OF CONTENTS}

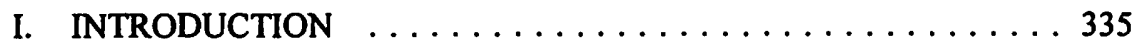

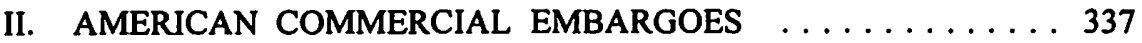

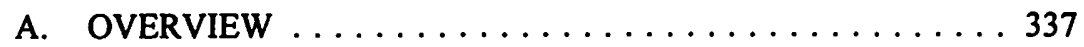

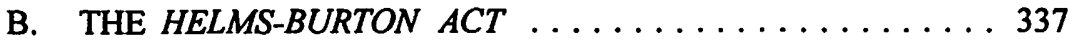

C. THE IRAN (LIBYA) OIL SANCTIONS BILL:

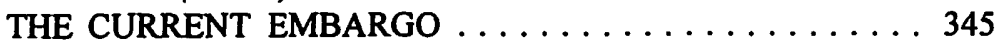

D. LIBYA, IRAQ AND NORTH KOREA $\ldots \ldots \ldots \ldots \ldots \ldots$

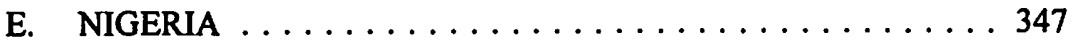

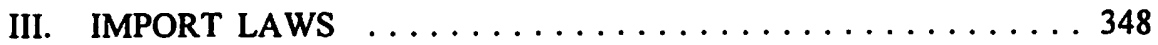

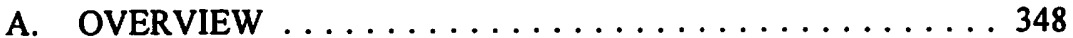

B. CHINA'S STATUS AS A MOST-FAVOURED NATION .. 348

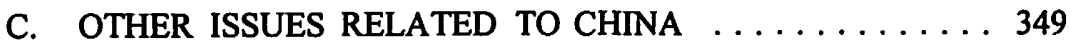

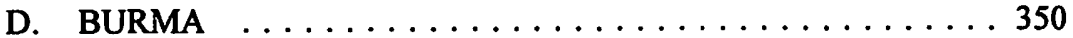

E. NARCOTICS ................... 350

F. TARIFF PREFERENCES $\ldots \ldots \ldots \ldots \ldots \ldots \ldots \ldots \ldots \ldots$

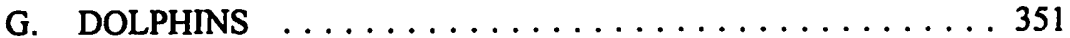

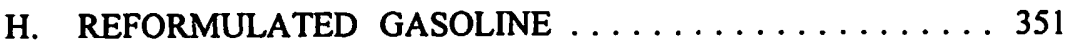

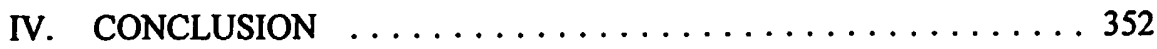

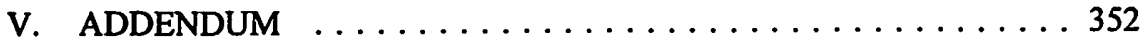

A. CONGRESSIONAL ACTION ON
IRAN/LIBYA SANCTIONS $\ldots \ldots \ldots \ldots \ldots \ldots \ldots \ldots 352$

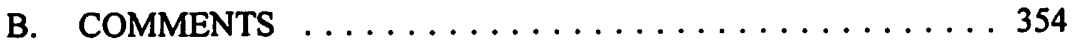




\section{l. INTRODUCTION}

The whole world is festering

With unhappy souls.

The French hate the Germans;

The Germans hate the Poles.

Italians hate Yugoslavs;

South Africans hate the Dutch.

And I don't like anybody very much!

- The Kingston Trio, Circa 1960

Some things don't change. One is the timelessness, and perhaps the world-view of the Kingston Trio. Another is the "silly season" that descends on Washington at regular, four-year intervals, about six months before each Presidential election. A third is a certain nativistic streak - always present, but usually not predominate - in the American electorate. They are an electorate that does not "like anybody very much," particularly if that anybody is different, and even more so if they are not only different but also foreign.

These three blights on the American political landscape (turmoil in international relations, election year politics, and aggressive extraterritoriality) converged in the spring of 1996 to produce two truly terrible pieces of American economic sanctions legislation. One of these pieces of legislation, the Cuban Liberty and Democratic Solidarity (LIBERTAD) Act of $1996,{ }^{1}$ was signed into law on March 12 in the emotional wake of Cuba's shooting down of two airplanes operated by the organization, "Brothers to the Rescue." The other, the Iran (Libya) Oil Sanctions Act of $1996,{ }^{2}$ is moving quickly through the Congress at this writing. ${ }^{3}$

Pub. L. No. 104-114, 110 Stat. 785 [hereinafter Helms-Burton Act].

$2 \quad$ S. 1228, 104th Cong., 1st Sess. (1995); H.R. 3107, 104th Cong., 2d Sess. (1996) [hereinafter Iran (Libya) Oil Sanctions Bill]. Although the title of the bill in both the House and the Senate remains the Iran Oil Sanctions Act of 1996, in fact both the House and Senate bills would apply the same sanctions to Libya. For clarity, the bill will be referred to in this article as the Iran (Libya) Oil Sanctions Bill. Subsequent to the writing of this article, the bill was enacted as Pub. L. No. 104172.

S. 1228, the principal sponsor of which is Senator Alphonse D'Amato (R-NY), passed the Senate by voice vote (without opposition) in December 1995. H.R. 3107 was approved by a vote of 32-0 by the House International Relations Committee in March 1996 and at this writing was being reviewed by the House Ways and Means Committee. President Clinton endorsed the Senate measure in the winter of 1996: P. Bluestein \& T.W. Lippman, "Allies Angered by U.S. Boycott Policy" Washington Post (10 May 1996) A1, A31. See also T.W. Lippman, "White House, Hill Agree on New Iran Sanctions; Both Parties Predict Quick Enactment of Bill" Washington Post (13 December 1995) A34. 
The Helms-Burton Act and the Iran (Libya) Oil Sanctions Bill are unprecedented, for the United States, in terms of the level of aggression directed at American allies and trading partners. Although engaged in legal actions, those allies and partners that choose not to conform to American embargoes of Cuba, Iran and Libya are the subject of such aggression. The measures carry real risks of sharp retaliation by the United States' best friends abroad, including Canada, the United Kingdom and Mexico; and any such retaliation is likely to affect American companies and company officials overseas. ${ }^{4}$ If enacted, the Helms-Burton Act and the Iran (Libya) Oil Sanctions Bill are certain to be challenged under the dispute-settlement procedures of the North American Free Trade Agreement ${ }^{5}$ and the World Trade Organization. ${ }^{6}$ In defending these challenges, the American Government will presumably be forced to invoke the "national security" exceptions in the General Agreement on Tariffs and Trade ${ }^{7}$ and NAFTA to justify these secondary boycotts against its historic best friends - an international political absurdity in and of itself. The outcome may draw into question the previously unfettered ability of the United States and other governments to invoke national security exceptions. In short, these laws remind us why extraterritorial sanctions are usually bad law and even bad domestic politics.

In a nutshell, the Helms-Burton Act authorizes American claimants to sue foreign companies that are "trafficking" in the property of the claimants that was nationalized by the Castro Government in the early 1960s. Successful claimants may recover triple the value of that property (which may include over thirty years of interest, added prior to the tripling) and, of course, attorneys' fees. The Iran (Libya) Oil Sanctions Bill would require the President to impose trade and/or financial sanctions against foreign companies (and perhaps their corporate parents, subsidiaries and affiliates) that invest more than U.S. $\$ 40$ million per year in, or export certain products or technology of benefit to, the oil and gas industries of Iran or Libya. ${ }^{8}$

Unfortunately, the Helms-Burton Act and the Iran (Libya) Oil Sanctions Bill represent extensions of, rather than abrupt departures from, existing American international economic legislation. It is a body of law that has grown increasingly preachy, unilateral and sanctions-oriented, largely in response to specific domestic

Canada, for example, has hinted strongly that it is readying legislation that would authorize Canadian companies to sue any American company that sues them under the Helms-Burton Act, and that would restrict entry into Canada for American citizens. See "Retaliation at U.S. on Cuba?; Canada Could Seize Assets, Require Visas" Toronto Sun (7 May 1996) 7. See also C. Goar, "May Fight U.S. Cuba Sanctions: Eggleton" Toronto Star (7 May 1996) Al4.

517 December 1992, 32 I.L.M. 289 [hereinafter NAFTA].

- "Agreement Establishing the World Trade Organization" set out in Final Act Embodying the Results of the Uruguay Round of Multilateral Trade Negotiations, 15 December 1993, 33 I.L.M. [hereinafter $W T O$ ].

730 October 1947, Can. T.S. 1947 No. 27, 55 U.N.T.S. 187, T.I.A.S. No. 1700 [hereinafter GATT].

s H.R. 3107, $\$ 4$, supra note 2. The impetus for the sanctions differs among the three target countries. As a communist dictatorship ninety miles from Florida, Cuba has long been a thorn in the American side - all the more so during an election year in which Florida's votes are pivotal. Iran is viewed as a major supporter of international terrorism and an opponent of Middle East peace. Libya is held responsible for the 1988 bombing of Pan Am Flight 103, which killed 259 people on the plane and eleven on the ground. Bluestein \& Lippman, supra note 3 at A31. 
political interests. This trend helped make the Helms-Burton Act and the Iran (Libya) Oil Sanctions Bill conceivable, and thus possible whenever triggering circumstances converge in an election year. Additional sanctions legislation - against Nigeria, for example - is waiting in the wings. Unilateral sanctions against China are being prepared as we write. This article discusses the potential effect of the Helms-Burton Act and the Iran (Libya) Oil Sanctions Bill on the oil industry. It shows why both pieces of legislation are likely to be unsustainable in light of such strengthened institutions as NAFTA and the WTO. Included is an analysis which questions the extent to which the GATT and NAFTA "national security" exceptions can be stretched. The article also places the Helms-Burton Act and the Iran (Libya) Oil Sanctions Bill (along with the various other measures still on the drawing boards) in the context of an increasingly aggressive American approach to economic sanctions.

\section{AMERICAN COMMERCIAL EMBARGOES}

\section{A. OVERVIEW}

American Presidents have exercised authority granted by Congress under the International Emergency Economic Powers $A c t^{9}$ to prohibit virtually all commerce between the United States and Cuba, Iran, Libya, Iraq, North Korea and certain areas of Angola. ${ }^{10}$

The embargoes of Cuba and North Korea extend explicitly to American subsidiaries abroad. The embargoes of Iran, Libya and Iraq do not at present cover American subsidiaries abroad if those subsidiaries are not exporting American goods, services or technology to embargoed countries and the American parent company does not approve or engage directly in a transaction with the embargoed country."

\section{B. THE HELMS-BURTON ACT}

\section{Cuba}

Although Cuba is not a major oil-producing country, it is of interest to the international petroleum industry for several reasons. First, there is a great deal of interest in new energy infrastructure projects in Cuba, such as power plants, transmission facilities, refineries, and chemical plants. This legislation will clearly complicate site selection. Second, probably because of the interest in energy infrastructure projects, numerous non-American oil companies have been identified in The authorities conferred by the two laws are similar, but the Trading With the Enemy Act is now used only in times of war or similar hostilities.

10 Regulations setting forth the rules of these embargoes are codified at 31 C.F.R. $\$ 500 \mathrm{ff}$ (1995). The embargoed areas of Angola are those held by the UNITA rebels.

" An American parent company also may not evade the embargoes, for example, by referring to an offshore subsidiary a transaction that the American parent could not do directly. See e.g. 31 C.F.R. $\S 535.208$ (1995). 
the media as potential "traffickers" subject to the sanctions of the Helms-Burton Act. Third, the Helms-Burton Act is a precedent that, if successful, could be applied in a variety of other circumstances where the United States desires to influence the conduct of foreign governments and persons.

\section{Pre-Helms-Burton Act}

The American embargo of Cuba is controversial because most American trading partners disagree with the policy, and because much emotion is generated by the proximity of Cuba to the United States and the fact that many refugees from Cuba live in the United States. The embargo has waxed and waned with American administrations and American-Cuban relations. First imposed in $1960,{ }^{12}$ the embargo was lifted with respect to American subsidiaries abroad in 1969 in response to enormous criticism from America's trading partners about American extraterritoriality. However, it was reinstated as a global embargo in October $1992 .{ }^{13}$ Currently, "persons subject to the jurisdiction of the United States," meaning not only persons in the United States and American citizens or permanent residents anywhere, but also entities anywhere that are controlled by American persons, are prohibited from engaging in virtually all types of transactions with Cuba unless they have received a specific licence from the U.S. Treasury Department's Office of Foreign Assets Control. Licences, not surprisingly, are not easy to get.

This means that a Canadian subsidiary of an American company cannot fill an order from Cuba without violating American law. Under the law, "knowing" or "wilful" violators are subject to criminal penalties of up to U.S. \$1 million and twelve years in jail, and other violators are subject to civil penalties of up to U.S. $\$ 250,000$. Under Canadian law, however, the American subsidiary cannot decline to fill the order from Cuba by reason of the American boycott, or upon instructions from the American parent company, without incurring potential civil and criminal penalties. This legal "Catch-22" is discussed in greater detail below.

\section{The Helms-Burton Act}

Named after its principal sponsors, Senator Jesse Helms (R-N.C.) and Representative Dan Burton (R-Ind.), the Helms-Burton Act languished as a bill in Congressional committees and was vigorously opposed by the Clinton Administration until two civilian aircraft were shot down by the Cuban air force in February of 1996. The bill was propounded by Cuban exile interests in South Florida and it was supported by those groups along with some of the American companies that held (and continue to 
hold) certified claims ${ }^{14}$ to property that was nationalized by the Castro Government between 1959 and 1961..$^{15}$

As enacted, the Helms-Burton Act codifies by statute the pre-existing embargo that had been imposed by Presidential Executive Order. This means that Congress has taken out of the President's hands the ability to modify or lift the existing embargo, so that in the future the embargo can only be changed by legislation.

The most aggressively extraterritorial provisions of the Helms-Burton Act are in Titles III and IV. Title III subjects foreign companies that "traffic" in confiscated Cuban property to lawsuits in American courts by American claimants. Title IV requires the U.S. Secretary of State to deny entry into the United States to corporate officers, principals or controlling shareholders of companies that "traffic" in confiscated property. It further requires the denial of entry to the agents, spouses, and "minor children" of such persons. ${ }^{16}$ It bears emphasis that this invitation to lawsuits against law-abiding companies of friendly countries, and this exclusion of their senior officials and their spouses and minor children, is triggered by acts entirely outside of American commerce that are legal in the "trafficker's" home country and in Cuba. Here is what Senator Jesse Helms, principal sponsor of the Helms-Burton Act and Chairman of the Senate Foreign Relations Committee, had to say about extraterritoriality and possible violations of the GATT and NAFTA, at the signing ceremony for the law in the White House Rose Garden:

SEN. HELMS: You got a question?

Q: $\quad$ Hi, I'm from Ciel y Mundo Network. You know the Cuban Government says repeatedly that this law is going to have no impact; that in reality the other governments are not going to pay attention to what it says; on the contrary it's illegal because it goes against NAFTA and GATT. What's your impression? Do you think -

The Helms-Burton Act was endorsed by the "U.S.-Cuba Business Council," see Senate, Cuban Liberty and Democratic Solidarity (LIBERTAD) Act of 1996 - Conference Report, 104th Cong., 2d sess., 142 Cong. Rec. S1504 (daily ed. 5 March 1996). However, it was opposed by one of the largest U.S. claimants, "Lone Star Industries," ibid. at S1488.

The Foreign Claims Settlement Commission, a U.S. Government agency, accepted petitions to certify claims in Cuba, and certified approximately 6,000 such claims, from 1966 to 1972 . See foreign Claims Settlement Comm'n Final Report of the Cuban Claims Program at 412 (1972). However, the Helms-Burton Act requires that the amount in controversy exceed U.S. $\$ 50,000$; in calculating this amount, the value is not tripled (see the Helms-Burton Act, supra note 1 s. 302(b). By some estimates this reduces the number of potential claims to around 700 , a number which still represents a significant amount of litigation. See e.g. 104th Cong., 2d sess., 142 Cong. Rec. S1480 (daily ed. 5 March 1996) statement of Senator Coverdell.

The Helms-Burton Act also prohibits American persons and agencies from extending loans or other financing to transactions involving Cuban property to which an American national has a claim, and requires the American Government to oppose Cuban membership in international financial institutions such as the World Bank, International Monetary Fund, and the Inter-American Development Bank. See the Helms-Burton Act, supra note 1., s. 104(a). 
SEN. HELMS: Well, will you deliver a message to the Cuban Government for me?

Q: $\quad$ Well, I can't -

SEN. HELMS: Dream on.

Q: - but I'm sure they're hearing it.

SEN. HELMS: Dream on."

It appears, in other words, that extraterritoriality was not a major concern of the Helms-Burton Act's principal sponsor.

For the purposes of Title III, which authorizes lawsuits, a "trafficker" is defined broadly as any person that "knowingly and intentionally":

(1) sells, transfers, distributes, dispenses, brokers, manages, or otherwise disposes of confiscated property, or purchases, leases, receives, possesses, obtains control of, manages, uses, or otherwise acquires or holds an interest in confiscated property;

(2) engages in a commercial activity using or otherwise benefiting from confiscated property; or

(3) causes, directs, participates in or profits from, trafficking (as described in the first two points above) through another person, without the authorization of any United States national who holds a claim to the property. ${ }^{18}$

In other words, if the Cuban Government nationalized an oil refinery in 1960, and in 1993 a Canadian company entered into a joint venture to manage a part of that refinery, the Canadian company might be sued as a "trafficker" in American courts if the Canadian company is subject to American jurisdiction. Typically, liability will be the amount certified to the claimant/plaintiff by the American Foreign Claims Settlement Commission, plus interest since 1960, that entire amount then tripled, plus attorneys' fees. Thus, an original claim of U.S. \$1 million will now equal about U.S. $\$ 17.5$ million (excluding attorneys fees). A claim for U.S. \$15 million will exceed U.S. $\$ 250$ million. The largest single certified claim exceeds U.S. $\$ 150$ million before adding interest and tripling. Estimates of the total value of the approximately 6,000 certified claims vary from U.S. $\$ 6$ billion to U.S. $\$ 100$ billion. More than 200 foreign companies, including many of the largest companies in Canada, Mexico, the United 
Kingdom and France, have been identified in the international media as potential "traffickers."19 One may assume that at least some American lawyers, whose fees are also to be paid by the hapless "traffickers," will not be reluctant to represent claimants.

Title III of the Helms-Burton Act becomes effective on August 1, 1996. However, no "trafficker" may be liable under the Act until three months after that date, which is November 1, 1996 - four days before the American election on November 5. ${ }^{20}$ The law authorizes President Clinton - if he dares - to suspend the August 1 effective date by up to six months if he determines and reports to the Congress, at least fifteen days before August 1, that the suspension is "necessary to the national interests of the United States and will expedite a transition to democracy in Cuba." ${ }^{.21}$ Regardless of whether the President exercises this waiver authority initially, he may later suspend the effective date of Title III in six-month increments for an indefinite period, upon making the same determination and report prior to each suspension. Although at present no one is making plans on the assumption that President Clinton will exercise this waiver authority on July 15 , it is possible that he or his successor may exercise that authority after the November 5 election. Since the Helms-Burton Act specifies that lawsuits which are pending at the time Title III is suspended will continue to conclusion, and since hypothetically the President could suspend Title III on the day after the election, there probably will be a race to the courthouses by plaintiff/claimants on November 1.22

Title IV of the Helms-Burton Act authorizes the denial of entry to the senior executives and the families of the senior executives of "traffickers." This Title has struck fear into every non-American corporate general counsel that his or her company's CEO or perhaps worse, the CEO's spouse and minor children, or even worse still, the said general counsel - will be stopped at the border and summarily deported on their next business trip or holiday. The State Department is charged with administering Title IV, and guidelines are currently being developed behind closed doors. While no one is certain when or how the axe might fall; what is known is that Title IV contains its own, separate definition of "trafficking." This definition appears to be slightly narrower than the Title III definition, and it emphasizes future "trafficking" instead of the mere passive holding of an existing interest. The Title IV definition covers anyone who:

See 104th Cong., 2d sess., 142 Cong. Rec. S1480 (daily ed. 5 March 1996) (statement of Sen. Dodd) at S1489, citing "U.S. and Cuba Economic Council, Inc."

A summary of Title III that was published by the Justice Department on May 17, 1996 clarifies the point that lawsuits cannot be filed until November 1 . The statute is somewhat ambiguous about whether lawsuits could be filed on August 1, even though "traffickers" could not be liable before November I. See 61 Fed. Reg. 24955 (1996). Helms-Burton Act, supra note 1, s. 306(b)(1). courts for an initial six-month period, and for a second six-month period that will end in August 1997. 
knowingly and intentionally

(i) transfers, distributes, dispenses, brokers or otherwise disposes of confiscated property,

(II) purchases, receives, obtains control of, or otherwise acquires confiscated property, or

(III) improves (other than for routine maintenance), invests in (by contribution of funds or anything of value, other than for routine maintenance), or begins after the date of the enactment of this Act to manage, lease, possess, use, or hold an interest in confiscated property,

(ii)

enters into a commercial arrangement using or otherwise benefitting from confiscated property, or

causes, directs, participates in, or profits from, trafficking (as described in clause (i) or (ii)) by another person, or otherwise engages in trafficking (as described in clause (i) or (ii)) through another person;

without the authorization of any United States national who holds a claim to the property. ${ }^{23}$

Thus, it appears not only possible, but also likely, that by mid-summer the American Immigration and Naturalization Service will begin denying entry to executives, and their families, of Canadian, Mexican, British, French and other companies that acted perfectly legally within their own jurisdictions but that have been branded "traffickers" by the extraterritorial reach of an American law enacted in an election-year frenzy. ${ }^{24}$

\section{Foreign Reactions}

The potential of the Helms-Burton Act for generating conflicts of near-trade war magnitude can scarcely be exaggerated. The 200-odd potential "traffickers" identified in the international media include some of the largest companies in Canada, Mexico, Japan and Western Europe. ${ }^{25}$ Governments of these countries and the European Union Commission will not sit silently while their nationals are sued in American courts and excluded from the United States for commercial activity that is legal in their countries

Helms-Burton Act, supra note 1, s. $40(\mathrm{~b})(2)(\mathrm{A})$. Note that legislative history makes it clear that divestiture of existing property in Cuba will not be regarded as "trafficking" for purposes of Title IV. See H.R. Conf. Rep. No. 468, 104th Cong., 2d Sess. (1996) at 66. Subsquently, the U.S. State Department issued orders excluding officials of Sherritt of Canada, and Grupo Domos, of Mexico. 
and that takes place entirely outside the United States. Already, Canada and Mexico have taken the first step toward a formal challenge to the Helms-Burton Act under the dispute-settlement procedures of NAFTA. The European Union has initiated similar dispute settlement proceedings in the WTO.

The main grounds for attacking the Helms-Burton Act under NAFTA and the WTO are likely to be the "national treatment" provisions of NAFTA and the GATT/WTO specifically that the Helms-Burton Act discriminates against non-American persons as compared with American nationals ${ }^{26}$ - and Chapter 16 of NAFTA, which prohibits new restrictions on the free movement of business travellers among the three NAFTA signatories. Both a large number of American commercial treaties, and customary international law, are also likely to be cited.

The American defence, if they are pushed to the wall, is likely to be the "national security" exceptions in art. XXI of GATT and art. 2102 of NAFTA, both of which provide an exception when signatories themselves believe that a measure is necessary for national security reasons. The American government may, however, be very reluctant to invoke these national security exceptions against its closest allies; both because it would be politically embarrassing, and because a questionable invocation of the national security exception to support a secondary boycott against friends could lead to scrutiny of, and perhaps limits on, the ability of American negotiators to invoke national security exceptions in the future. If the American government does not invoke the "national security" exceptions, then it can only argue for interpretations of the NAFTA provisions on "free movement of business travellers," and the NAFTA and GATT provisions on "national treatment" that would not cover Titles III and IV of the HelmsBurton Act. Such arguments are slender reeds on which to lean, especially before international panels that are not likely to be sympathetic.

Retaliatory measures are another possibility. Already Canada has a "blocking order" that prohibits persons within Canada, including American citizens and subsidiaries of American companies, from complying with the American embargo of Cuba. ${ }^{27}$ This blocking order is backed by stiff fines and possible prison sentences. The United Kingdom has a blocking order similar to that of Canada. ${ }^{28}$ Among the possibilities for retaliation are the seizing of assets of American subsidiaries that sue "traffickers" under

The national treatment provisions are found in Chapter 3 of NAFTA, and Article III of the GATT. Foreign Extraterritorial Measures (United States) Order, 1992, SOR92-584. There is an irreconcilable conflict - a "Catch-22" - between the American embargo and the Canadian blocking order. Where, for example, a Canadian subsidiary of an American company receives an order for sales to Cuba the subsidiary would violate American law if it were to make the sales, and would violate Canadian law if it did not do so because of the American embargo. There is no simple way to resolve the conflict. The best advice to American and Canadian companies caught in this conflict is to avoid compounding the situation by creating a double violation (e.g. an American parent telling its Canadian subsidiary to go ahead and obey Canadian law, which might constitute two violations of American law). So far, it appears that both American and Canadian authorities have tried to avoid head-on enforcement conflicts, but that may change as American enforcement of the Helms-Burton Act creates more visible conflicts.

Protection of Trading Interests (American Cuban Assets Control Regulations) Order 1992, S.I. $1992 / 2449$. 
Title III of the Helms-Burton Act and the denial of entry for American persons to some other countries. ${ }^{29}$ Some American executives might be advised to keep on hold plans for family vacations abroad in August.

\section{Significance for Oil Industry}

The Helms-Burton Act affects the petroleum industry in several ways. First, numerous oil companies are already being implicated in a "Hall of Shame" comprised of supposed "traffickers" in confiscated Cuban property - that is being widely circulated in the international press. ${ }^{30}$ This list contains so many oil companies that they need to be grouped by country:

Brazil: $\quad$ Petrobras, S.A.

Canada: Anglers Petroleum International Bow Valley Industries Ltd.

Northwest Energy Ltd.

Fremont Resources

Fortuna Petroleum

Fraemasten

Heath \& Sherwood

France: Total

Bourgoin

Compagnie Europeane des Petroles

CFD

Mexico: Pemex

Mexpetrol

Mexican Petroleum Institute

Equipos Petroleos Nacionales

United

Kingdom: British Barneo PLC

Castrol

Premier Consolidated Oilfields

Simon Petroleum Technology

These companies will be under intense pressure to divest their Cuban investments, or to press their governments to impose retaliatory measures against American companies.

Second, other oil companies will be strongly discouraged from investing in Cuba, and, perhaps, out of an excess of caution, from trading with Cuba (which is not prohibited by any reasonable interpretation of the Helms-Burton Act). Some companies, particularly those in Canada and the United Kingdom, may find themselves caught in 
the middle between the Helms-Burton Act and the Canadian and British blocking orders.

Third, the resolution of the controversy surrounding the Helms-Burton Act on the international stage will establish an important precedent one way or another. If such an aggressive extraterritorial measure succeeds in effectively forcing mass divestitures without being successfully challenged, then the world can expect more such measures - at least every four years. If, on the other hand, the United States is forced to defend the Helms-Burton Act in international fora, to endure scrutiny of any invocation of a "national security" exception, and to face the possibility of countermeasures by trading partners so that this unfortunate piece of election-year legislation is repealed or allowed to become a dead letter, then another precedent - that of resisting such measures, and subjecting them to international disciplines - will have been established.

\section{THE IRAN (LIBYA) OIL SANCTIONS BILL: THE CURRENT EMBARGO}

In March 1995, following publicity about a proposed investment by Conoco in an Iranian oil field, President Clinton issued an Executive Order banning investment by American persons and companies in Iranian oil and gas ventures. ${ }^{31}$ In May, the President issued a second order banning American persons from transacting business of almost any type with Iran. ${ }^{32}$ When the Administration could not persuade other governments to join this embargo, Senator Alphonse D'Amato (R-NY) and Congressman Ben Gilman (R-NY) proposed legislation that was intended to achieve indirectly the same objective - pressuring foreign companies to adhere to the American embargo - by imposing a secondary boycott on foreign companies that invest in Iran or trade with Iranian oil and gas ventures. In the Senate, Libya was added as an afterthought at the request of Senator Edward Kennedy (D-Mass.).

This bill passed the Senate on a voice vote without apparent dissent in December 1995 , and it is nearing readiness for a floor vote in the House. The State Department, representing the President, apparently believes that there is little to be gained by supporting Iran and Libya this year and has indicated that the President would sign the Senate version of the bill, which was moderated by the State Department's lobbying.

The Senate bill would impose a secondary boycott on foreign companies that invest more than U.S. $\$ 40$ million in Iran or Libya (or that make four investments of at least U.S. $\$ 10$ million during any twelve-month period). The more extreme House International Relations Committee bill would add a "trade trigger," sanctioning companies that export to Iran or Libya certain petroleum- and natural gas-related goods and technology. Under the House version, the President would have to impose on sanctioned foreign companies two of the following five sanctions: (1) the denial of access to American Export-Import Bank assistance; (2) the prohibition of imports from the foreign company and American exports to that company; (3) the prohibition of loans from American financial institutions in excess of U.S. $\$ 10$ million during any 
twelve month period; (4) the denial of access to American Government procurements; and (5) where the sanctioned person itself is a financial institution, the prohibition of their serving as primary dealers in American bonds or as repositories for American Government funds. ${ }^{33}$

These sanctions would extend not only to a sanctioned foreign company that dealt directly with Iran but also to its wholly owned subsidiaries, its other subsidiaries and affiliates that knew of and engaged in the prohibited activities, and its parent company if the parent knew or had reason to know of the prohibited activities. The foreign company's transactions with Iran need not have any connection whatever with the United States. From a procedural standpoint, this will require an American government fact-finding on a transaction in a country where the United States has neither diplomatic nor commercial relations and where it quite possibly lacks jurisdiction over the key actors.

These sanctions represent to an extraordinary degree, a unilateral American attempt to govern the commercial behaviour of foreign entities operating entirely outside the United States. The message, as the sponsors of the legislation have frequently said, is "you can trade with them or you can trade with us. ${ }^{134}$

As with the Helms-Burton Act, the Iran (Libya) Oil Sanctions Bill, if enacted, is likely to be the subject of GATT/WTO challenges and possible retaliatory measures. Again, the United States may be forced to invoke the "national security" exception, and in doing so it may find that exception scrutinized and rendered more difficult to use in the future.

Both the Senate and the House versions of the Iran (Libya) Oil Sanctions Bill would authorize the President to delay the imposition of sanctions for up to ninety days in order to consult with relevant foreign governments, and for a second ninety day period if the President notified Congress that the relevant foreign government was in the process of securing the compliance of its citizen with American law. Both bills would authorize the President to waive sanctions altogether if he reported to the Congress that the waiver was important to the national interest.

\section{LIBYA, IRAQ AND NORTH KOREA}

In addition to being covered by the Iran (Libya) Oil Sanctions Bill, a pre-existing American embargo prohibits American citizens and persons in the United States from doing business with Libya. ${ }^{35}$ This embargo, however, does not prohibit American subsidiaries abroad from engaging in commerce with Libya as long as those subsidiaries are not exporting American-origin goods or technology and provided that

The Senate bill requires the President to impose only one sanction and does not include the ban on imports. Firms; House Measure Targets Trade with Iran, Libya" Washington Post (22 March 1996) A31. 
the American parent has not approved, facilitated, guaranteed, financed or otherwise arranged the transaction. The American embargo of Iraq is very similar to the embargo of Iran in all important respects. ${ }^{36}$

These embargoes are strictly enforced by the American Treasury Department's Office of Foreign Assets Control. They include requirements that American banks freeze any assets of embargoed countries that may come under the control of those banks. One foreign oil company learned this the hard way when a payment to that company, for Libyan crude oil, was inadvertently routed through an American bank which froze the funds. They remain frozen today.

\section{E. NIGERIA}

Last year, Ken Saro-Wiwa (an Ogoni political agitator) and several of his cohorts were accused, tried, convicted and summarily executed in November on charges of inciting a riot in which a number of people were killed, including some traditional tribal leaders. These hangings were widely publicized in the Western press. Governments and non-governmental organizations charged that the proceedings lacked fundamental fairness, particularly the absence of any appeal. Soon thereafter, legislation was introduced in the American Congress calling for Nigeria to be added to that list of countries that the United States embargoes entirely or in part. The legislation would codify existing sarctions as well as institute new ones, ${ }^{37}$ subject to a Presidential waiver. ${ }^{38}$ This legislation would codify current sanctions which ban foreign aid, military sales, export financing and air flights between the United States and Nigeria and require the United States to oppose loans or assistance to Nigeria in international financial institutions, including the World Bank. The bill would also codify an existing visa ban on all Nigerians who formulate, implement, or benefit from, policies that hinder Nigeria's transition to democracy. ${ }^{39}$

Both bills would prohibit all American investment in Nigeria including new investments in the energy sector. The Senate version specifically prohibits all American investment or participation in the liquified natural gas project at Bonny, Nigeria. ${ }^{40}$ Both bills would also freeze the personal assets invested in the United States of top Nigerian officials. Both bills further suggest that Nigeria should be excluded from international sports competition including the 1996 Summer Olympic Games in Atlanta.

The Senate bill also calls on the President to seek an international, and if necessary, unilateral, arms and oil embargo against Nigeria. ${ }^{41}$

The American embargo of North Korea, like the embargo of Cuba, covers foreign subsidiaries of American companies anywhere in the world. See ibid.

S. 1419, 104th Cong., 1st Sess. (1995); H.R. 2697, 104th Cong., 1st Sess. (1995).

The President could waive imposition of these sanctions if he certified to Congress that Nigeria had released all political prisoners, and demonstrated an unequivocal commitment to human rights and democratic government, and that this waiver was in the national interest.

Proc. No. 6,636, 48 Fed. Reg. 65,525 (1993).

Supra note 37, s. 7419, s. 4(7)(A).

Ibid., s. 1419, s. 5(b)(2). 
At this writing, no legislation has been enacted, though Senate hearings have been held. The State Department says it has been attempting, apparently unsuccessfully, to secure the cooperation of other countries in multilateral sanctions; however, these efforts are continuing. If the $\mathrm{Cuba} / \mathrm{Iran} / \mathrm{Libya}$ approach is successful, the lack of international cooperation may not restrain yet another effort to shut down commerce with this unfavoured oil-rich country.

\section{IMPORT LAWS}

\section{A. OVERVIEW}

A maze of U.S. Congressional enactments makes access to the U.S. market conditional, based on a trading partner's immigration policies, narcotics enforcement, human rights, intellectual property protection, nuclear weapons proliferation and dolphin preservation. Virtually all of these laws have been enacted within the past twenty-five years. They come mainly from the Congress which has tried increasingly to restrict the President's discretion in matters of foreign policy in recent times.

\section{B. CHINA'S STATUS AS A MOST-FAVOURED NATION}

One of the oldest American rules conditioning market access on foreign behaviour is the Jackson-Vanik Amendment, which prohibits communist countries that were not receiving most-favoured nation ("MFN") treatment from the United States in 1974 from receiving MFN benefits after that date unless the President certifies to the Congress that those countries allow free emigration or are taking significant steps toward freedom of emigration. ${ }^{42}$ Originally aimed at the Soviet Union, the original Jackson-Vanik has little remaining application to countries other than Cuba, Vietnam and China. ${ }^{43}$

Although freedom of emigration has little relevance to China (it is said that Chinese leaders, when confronted with Jackson-Vanik, ask their American counterparts how many Chinese emigrants they want!), each year the President must waive the JacksonVanik prohibition on China's receipt of MFN benefits because China, a communist country, was not receiving MFN treatment at the time of the enactment of the JacksonVanik in 1974. By statute, the Congress may disapprove this Presidential waiver within thirty days. In 1993, President Clinton issued an Executive Order that tied renewal of most-favoured nation treatment to China's performance on several human rights issues. ${ }^{44}$ In renewing China's MFN in 1994, however, the President stated that he would no longer link renewal of MFN to many of these human rights issues. ${ }^{45}$ Jackson-Vanik].

43 Ironically, Iran and Iraq have MFN status, although all American commercial contact is cut off through other measures. 
Thus, MFN is a ready-made annual legislative vehicle for venting any and all frustrations which American interest groups have with Chinese performance on a wide array of issues. The granting of MFN treatment to China is, therefore, a major annual headache for American Presidents, and a high annual uncertainty for any energy company trying to do or finance a multi-year project in this most attractive of markets.

On May 20, 1996, President Clinton announced that on June 3 he would recommend to Congress the renewal of China's MFN status. Both houses of Congress will have thirty days after June 3 during which to override the President's MFN recommendation.

\section{OTHER ISSUES RELATED TO CHINA}

With China, the American government has other problems. On May 15, 1996, Acting American Trade Representative Charlene Barshefsky announced that the United States would impose retaliatory tariffs of 100 percent on U.S. \$2 billion worth of imports from China unless the Chinese government improved its enforcement of a bilateral agreement to end piracy of $\mathrm{CDs}$, videos and music recordings. For good measure, Barshefsky released a list of Chinese products from which the imports subject to retaliation would be chosen. ${ }^{46}$

The energy/environmental policy implications of the American China sanctions policy are significant. China is heavily dependent on coal and will soon be the world's largest coal burner and the world's largest emitter of coal-borne pollutants including carbon dioxide, which causes global warming. Any sound Western approach should encourage alternative energy sources. Abundant oil and natural gas reserves have not been encountered in China. China considers that nuclear power should play a role in its energy future, and would like to acquire American technology and equipment, as well as construction and operations expertise. China is a signatory to the Nuclear NonProliferation Treaty. Yet until recently, self-imposed American restrictions still limited the ability of American companies to be active in this market. ${ }^{47}$ As a result of recent changes, American companies may now sell steam turbine generators and so-called "conventional balance-of-plant" equipment. They cannot sell reactor equipment and other power island components. There are fewer restrictions, however, on American companies licensing such technology to foreign companies for manufacturing and construction. French, Japanese and Canadian companies benefit from this policy which harms American companies and sets back American energy/environmental policy. For

46 "Tough on China" Washington Post (16 May 1996) A28. This announcement came on the heels of a decision by the Clinton Administration not to retaliate against China for a sale of nuclear materials to Pakistan.

17

Following President Clinton's decision on May 10, 1996, to absolve the Chinese Government for the transfer of high-technology "ring magnets," which could be used to make nuclear weapons, the American Export-Import Bank announced that it would go ahead with the financing of a $\$ 120$ million nuclear plant in China. See "China May Get Money From American For Plant" The Journal of Commerce (20 May 1996) Al. Had President Clinton not cleared China in the sale to Pakistan, American laws designed to discourage nuclear proliferation would have required that China be denied access to Export-Import Bank financing, and the $\$ 120$ million power project would have gone to European companies instead of to Westinghouse, ibid. 
example, American companies were not able to compete on the recent Daya Bay Phase I \& II and Qinshan Phase III nuclear power plant projects, which were awarded to French and Canadian suppliers, respectively. The Chinese have a hard time understanding why the United States continues to adhere to this policy.

\section{BURMA}

On April 23 1996, a nationwide boycott of PepsiCo products and fast-food subsidiaries by American college students led PepsiCo to announce that it would withdraw from a large joint venture in Burma. Members of Congress, who do not like to fall behind public sentiment on a human rights issue in an election year, promptly scheduled hearings on the proposed Burma Freedom and Democracy Act of 1995, ${ }^{48}$ which would impose an embargo on American commerce with Burma including large American oil exploration and development projects in that country. This bill, like the Helms-Burton Act, had been languishing until a triggering event occurred in an election year. Passage of the Burma embargo by the Republican-led Congress would force President Clinton to choose between signing the bill and angering business, or vetoing it and angering students and human-rights advocates in the run-up to the election. ${ }^{49}$

\section{E. NARCOTICS}

The President is required by law to identify and notify Congress of major "drug producing countries" and major "drug-transit countries" that are not cooperating fully with the United States or taking steps on their own to prevent drug trafficking into the United States, money laundering, or bribery and other corruption that facilitates drug production. ${ }^{\text {so }}$ These countries are subject to sanctions that include additional import duties of fifty percentage points, denial of American programs that accord preferential tariff treatment, and denial of access to the United States by national air carriers of sanctioned countries. The President has wide discretion in choosing countries and sanctions. ${ }^{51}$

\section{F. TARIFF PREFERENCES}

For developing countries generally, and specifically for Andean and Caribbean countries, the President determines eligibility for preferences subject to Congressionally established statutory criteria. ${ }^{52}$ These criteria include the exclusion from eligibility for

48 S. 1511, 104th Cong., 1st sess. (1995); H.R. 2892, 104th Cong., 2nd sess. (1996).

19 "Boycott of Burma bill takes on new life as public protest fuels Congressional interest" The Boycott Reporter (13 May 1996) 4.

so $\quad$ Narcotics Control Trade Act, 19 U.S.C.A. $\$ \S ~ 2491-2495$ (West Supp. 1996).

st It is widely believed, for example, that Colombia was recently sanctioned because of the unpopularity of President Samper rather than lack of efforts, and that Syria and Lebanon have not been sanctioned possibly because of Middle-East peace talks.

52 Very similar rules pertain to the American Generalized System of Preferences Renewal Act of 1984, 19 U.S.C.A. \$\$ 2461-2465 (West Supp. 1996), which provides duty-free treatment for many products from developing countries; the Andean Tariff Preference Act, 19 U.S.C.A. \$§ 3201-3206 (West Supp. 1996); and the Caribbean Basin Economic Recovery Expansion Act of 1990, 19 
preference of countries that have interfered with intellectual property rights of American citizens, refused to recognize arbitral awards in favour of American citizens, aided and abetted international terrorism, or failed to take steps to afford internationally recognized worker rights.

\section{G. DOLPHINS}

American law prohibits the import of yellow-fin tuna or tuna products from countries that do not follow "dolphin safe" practices. ${ }^{53}$ This law gave rise to the well-known "Tuna Dolphin Cases" initiated by the Mexican government and the Commission of the European Union against the United States under GATT dispute-settlement procedures. ${ }^{54}$ In those cases, the American prohibition was found to violate the GATT "national treatment" requirements and not to be saved by the GATT exception for "measures necessary to the conservation of exhaustible natural resources," largely because the law attempted to apply American standards to tuna fishing on the high seas. The American Government blocked acceptance of the dispute-settlement panel reports by the political-level GATT Council, and a resolution of the disputes remains under negotiation at this writing.

\section{H. REFORMULATED GASOLINE}

American gasoline regulations implementing the Clean Air $\mathrm{Act}^{55}$ set standards for gasoline cleanliness that were intended to reduce air pollution from motor vehicle emissions. In prohibiting the sale of gasoline whose cleanliness fell below 1990 levels, the regulations allow most American domestic producers of reformulated and conventional gasoline to set their baseline levels of cleanliness individually, according to average levels in their own 1990 gasoline; but the regulations require importers and foreign refiners, in most instances, to meet statutory standards that equal average pollutant levels of all 1990 American gasoline. Brazil and Venezuela challenged those American gasoline regulations in the WTO, arguing that the regulations discriminated against foreign suppliers and, thus, violated the "national treatment" provisions in Article III of the GATT.

In January 1996, a WTO dispute-settlement panel agreed with Brazil and Venezuela. ${ }^{56}$ The American government appealed the issue to a GATT appellate body but lost there also. ${ }^{57}$ As of May 1, 1996, the WTO members had not yet adopted the report. The United States will have thirty days after formal adoption of the report to

U.S.C.A. \$§ 2701-2707 (West Supp. 1996).

53 Marine Mammal Protection Act of 1972, 16 U.S.C. $\$ 1371$ (a)(2) (1988).

s4 GATT, United States - Restrictions on Imports of Tuna, Panel Report (3 September 1991) 30 I.L.M. 1594; GATT, United States - Restrictions on Imports of Tuna, Panel Report (16 June 1994) 33 I.L.M. 839. 40 C.F.R. $\$ 80.40$ ff (1995).

"Kantor Says He's Inclined to Appeal Panel's Ruling in Venezuelan Gas Case" (1996) 13 Int. Trade Rep. 100.

37 "Appellate Body Faults American in Gas Case, But Reverses on Conservation Exception" (1996) 13 Int. Trade Rep. 703. 
make a decision on how to respond. If the United States does not change its regulations, Venezuela and Brazil will have the right to seek compensation or commensurate tariffs on American goods. ${ }^{58}$

\section{CONCLUSION}

Not all sanctions legislation is objectionable. Reasonable controls on the export and re-export of products and technology that are capable of military or terrorist applications have long been generally accepted among trading partners. Exceptions to the GATT rules for protection of life or health, conservation of exhaustible natural resources, and genuine national security concerns have long been codified and accepted. Some specific concerns, such as intellectual property protection, are governed by rules of the WTO. Others, such as protection of worker rights, are strong enough as domestic political issues to justify qualifications on access to American Government benefits (e.g. tariff preferences) when applied to persons doing business directly with the United States.

The line appears to be crossed, however, where one government attempts to impose sanctions on the citizens of another for activities of which the sanctioning country disapproves, even though those activities take place entirely outside the commerce of the sanctioning country and are legal in the jurisdictions where they take place. That is what international organizations, agreements and relations - "Foreign Relations," to use the title of the Senate Committee that Senator Helms chairs - are all about.

It appears that the fruits of this year's "silly season" will be scrutinized in the sober light of the WTO and NAFTA dispute-settlement proceedings. The precedents that will be established by those cases, and more broadly by the handling of conflicts that will arise over the Helms-Burton Act and the Iran (Libya) Oil Sanctions Bill, will influence the direction of American extraterritorial legislation for years to come.

\section{ADDENDUM}

\section{A. CONGRESSIONAL ACTION ON IRAN/LIBYA SANCTIONS}

\section{Update on the Bill's Progress}

On 13 June 1996, the House Ways \& Means Committee passed by unanimous voice vote an amended version of H.R. 3107, the Iran and Libya Sanctions Act of 1996, which would impose a secondary boycott on non-American companies that undertake certain activities with respect to Iran and Libya. This Ways \& Means bill is the result of negotiations with the Clinton Administration, members of the House International Relations Committee (which passed the first version of H.R. 3107), the House Banking Committee and various other interests. The Ways \& Means bill is expected to pass the House, re-pass the Senate, and be signed into law by the President by early July of 1996. Key provisions of the Ways \& Means bill are summarized below. 


\section{Activities Triggering Sanctions}

The President will be required to impose secondary-boycott sanctions against persons that, after the date of enactment, knowingly invest within a twelve-month period U.S. $\$ 40$ million or more that "directly and significantly" contributes to the development of petroleum resources in Iran. The President may, at his discretion, impose sanctions against persons that make such investments with respect to Libya. The President also will be required to impose sanctions against persons that knowingly export goods, services or technology to Libya in violation of United States Security Council Resolutions 748 or $883 .^{59}$

\section{Types of Sanctions}

Where mandatory sanctions are triggered, the President must choose and impose two (and where discretionary sanctions against Libya are triggered, the President must impose one) of the following six penalties:

(1) denial to sanctioned persons of benefits of the American ExportImport Bank;

(2) denial of approval of specific export licences ${ }^{60}$ for exports to sanctioned persons;

(3) loans to sanctioned persons from American financial institutions in excess of $\$ 10$ million in any twelve-month period;

(4) restrictions on American imports "with respect to" sanctioned persons to the extent that such restrictions are already authorized under the United States International Emergency Economic Powers Act; ${ }^{61}$

(5) prohibition on the designation of a sanctioned financial institution as a principal dealer in American government debt instruments, and prohibition of a sanctioned financial institution from serving as a repository of American government funds;

(6) prohibition of American government procurement of goods or services from a sanctioned person - but with broad exceptions including (a) compliance with the WTO Government Procurement Code; (b)

Those resolutions prohibit exports to Libya that contribute significantly and materially to (a) Libya's ability to acquire chemical, biological or nuclear weapons or destabilizing numbers and types of advanced conventional weapons, or Libya's military or paramilitary capabilities; (b) Libya's ability to develop its petroleum resources; or (c) Libya's ability to maintain its aviation capabilities. 
existing contracts; (c) sole-source suppliers of defense articles; (d) essential spare parts; and (e) humanitarian items.

\section{Persons Sanctioned}

In addition to companies or other persons that knowingly and directly engage in sanctioned activities, and their successors, the bill will extend sanctions to (a) parent or subsidiary companies that "with actual knowledge have engaged in" the sanctioned activities, and (b) controlled-in-fact subsidiaries and affiliates that "with actual knowledge engaged in" sanctioned activities.

\section{Delay and Waiver of Sanctions}

The President may delay the imposition of sanctions for up to ninety days, in order to consult with the government of the sanctioned person. The President may delay sanctions for a second ninety-day period if he certifies to the Congress that the foreign government is taking specific and effective actions to terminate the act that gave rise to the sanctions.

The President may waive the imposition of sanctions in two ways. First, he may waive sanctions altogether by reporting to the Congress that the waiver is important to the American national interest. Second, he may waive sanctions with respect to nationals of any country that has agreed to impose substantial economic penalties that will inhibit the support of terrorism and development of weapons of mass destruction.

It is unlikely that the President will exercise this waiver authority, particularly in the period before the presidential election in November. Once imposed, sanctions are to remain in effect for at least two years unless the sanctioned activity ceases.

\section{B. COMMENTS}

First, it is unfortunate that the American Congress is seeing fit to pass, and the President is seeing fit to sign, what is very probably the first true secondary boycott in American history. Coming on the heels of the Helms-Burton Act - which is aggressively extraterritorial, although not strictly-speaking a secondary boycott - this legislation indicates a harshly unilateral direction for American foreign economic policy, even by past election-year standards. The Ways \& Means bill, however, could have been worse. In earlier versions, the President would have been given new authority, and strong encouragement, to impose import restrictions as a sanction which almost certainly would have triggered WTO violations; and, mandatory sanctions would have been triggered by either investing in or trading with Iran or Libya.

Second, the investment sanctions are only triggered by investments that are entered into after the date of enactment, pursuant to contracts that are entered into after the date 
of enactment. ${ }^{62}$ Thus, it probably will take some time for sanctioned persons to be identified.

Third, several future interpretations will affect the operation of this legislation, including (a) the degree of involvement by a parent, subsidiary or affiliate of a sanctioned person that is necessary to constitute "engaging in" the sanctioned transaction and, thus, to extend sanctions to the parent, subsidiary or affiliate, and (b) the precise meaning of the term "investment" - which triggers sanctions — as applied to complex transactions.

Finally, there is a strong possibility that future American sanctions will be challenged in WTO dispute-settlement proceedings. The outcome will, of course, depend on the facts, and whether the American government is willing to invoke the GATT's "national security" exception to defend, in essence, sanctions against its friends. 